\title{
Impact of major volcanic eruptions on stratospheric water vapour
}

\author{
Michael Löffler, Sabine Brinkop, and Patrick Jöckel \\ Deutsches Zentrum für Luft- und Raumfahrt (DLR), Institut für Physik der Atmosphäre, Oberpfaffenhofen, Germany \\ Correspondence to: Patrick Jöckel (patrick.joeckel@dlr.de)
}

Received: 26 November 2015 - Published in Atmos. Chem. Phys. Discuss.: 8 December 2015

Revised: 14 April 2016 - Accepted: 17 May 2016 - Published: 30 May 2016

\begin{abstract}
Volcanic eruptions can have a significant impact on the Earth's weather and climate system. Besides the subsequent tropospheric changes, the stratosphere is also influenced by large eruptions. Here changes in stratospheric water vapour after the two major volcanic eruptions of El Chichón in Mexico in 1982 and Mount Pinatubo on the Philippines in 1991 are investigated with chemistry-climate model simulations. This study is based on two simulations with specified dynamics of the European Centre for MediumRange Weather Forecasts Hamburg - Modular Earth Submodel System (ECHAM/MESSy) Atmospheric Chemistry (EMAC) model, performed within the Earth System Chemistry integrated Modelling (ESCiMo) project, of which only one includes the long-wave volcanic forcing through prescribed aerosol optical properties.

The results show a significant increase in stratospheric water vapour induced by the eruptions, resulting from increased heating rates and the subsequent changes in stratospheric and tropopause temperatures in the tropics. The tropical vertical advection and the South Asian summer monsoon are identified as sources for the additional water vapour in the stratosphere. Additionally, volcanic influences on tropospheric water vapour and El Niño-Southern Oscillation (ENSO) are evident, if the long-wave forcing is strong enough.

Our results are corroborated by additional sensitivity simulations of the Mount Pinatubo period with reduced nudging and reduced volcanic aerosol extinction.
\end{abstract}

\section{Introduction}

As the most important greenhouse gas in the troposphere, water vapour plays a key role in the climate feedback loop. This feedback amplifies the greenhouse effect of $\mathrm{CO}_{2}$ by about $60 \%$ (Forster et al., 2007). Aside from the water vapour distribution in the troposphere, the amount of water vapour in the stratosphere is also relevant for the climate (Solomon et al., 2010). The abundance of stratospheric water vapour (SWV) is mainly controlled by the temperatures at the tropical tropopause (Mote et al., 1996). It is further subject to a high inter-annual and multi-decadal variability, mostly dominated by the quasi-biennial oscillation (QBO) and El Niño-Southern Oscillation (ENSO), which both affect tropical tropopause temperatures (Dessler et al., 2014b). Besides the two well-known phenomena, changes in the chemical balance (like higher methane oxidation rates through an increase of stratospheric chlorine, hydroxyl and ozone), changes in circulation patterns, and volcanic influences have to be taken into account (Forster et al., 2007; Stenke and Grewe, 2005).

The effect of volcanoes on the climate system was investigated with models under different aspects. Stenchikov et al. (1998) addressed the radiative impact of Mount Pinatubo aerosols. They used observational data of aerosol extinctions and effective radii to calculate the radiative forcing with the ECHAM4 general circulation model and found that the stratospheric heating was mainly due to near-infrared solar forcing. Arfeuille et al. (2013) investigated the uncertainties of the Mount Pinatubo aerosol extinction and the effect on temperature. Thomas et al. (2009a, b) were the first to use a comprehensive and complex simulation of the ECHAM5 general circulation model to evaluate the effects of the Mount Pinatubo eruption under different boundary conditions, taking into account observed sea surface temperatures (SSTs) and volcanically induced ozone anomalies, as well as QBO and ENSO. They were able to realistically reproduce the observed lower stratospheric temperature response with the combined effects of the prescribed SSTs, ozone anomalies, and the state of the QBO. Graf et al. (1993) used the ECHAM2 general circulation model to investigate the strato- 
spheric aerosol effects of El Chichón and Mount Pinatubo on the climate of the Northern Hemisphere (NH). They identified short-term dynamical responses and a warming of the lower troposphere in the first winter season after the eruptions, which they found to be in good agreement with observations. With the MAECHAM4/CHEM (Middle Atmosphere European Centre for Medium-Range Weather Forecasts Hamburg (version 4)/Chemistry) model Timmreck and Graf (2006) performed a model study to simulate the radiative effects and the dispersal of the aerosols after the eruption of a super volcano in the mid-latitudes of the $\mathrm{NH}$. They discovered that the initial dispersal of the aerosol cloud mainly depends on the season of the eruption. In summer, the cloud is transported west- and northward, in winter more southand eastward. Contrary to the heating found in other studies after the Pinatubo eruption, Timmreck and Graf (2006) determined a strong cooling of $\sim-1.6 \mathrm{Kd}^{-1}$ in the upper stratosphere shortly after the eruption of the super volcano. The dispersal of the Mount Pinatubo aerosol cloud was investigated with the ECHAM4 model by Timmreck et al. (1999a) using a Newtonian relaxation technique. Their simulated aerosol distribution was mostly in good agreement with observational data. Timmreck et al. (1999b) also used the ECHAM4 model to perform an interactive simulation with prognostic aerosols for the Mount Pinatubo eruption. They then compared the results for the years 1991 and 1992 with a non-interactive study, satellite observations, and in situ measurements. They were able to reproduce dynamical effects in accordance with observations and found maximum heating rates of $\sim 0.3 \mathrm{Kd}^{-1}$ in October 1991 .

Regarding the changes in stratospheric water vapour in the aftermath of major volcanic eruptions, Angell (1997) found in the limited observational data available that there is a SWV increase after volcanic eruptions, which disappeared after approximately 2 years. Joshi and Jones (2009) proposed that within the following 2 years after the eruption, a heating of the tropopause layer imposed by volcanic aerosol clouds allowed more water vapour to pass into the stratosphere. They supposed that the total SWV perturbation (globally averaged) after the Mount Pinatubo eruption would account for at least $15 \%$ more SWV. The increase in tropopause temperatures supported the investigations of Considine et al. (2001). They also made volcanic eruptions partly responsible for the SWV trend in the 1990s. In their model simulation they determined an increase in tropopause temperatures of about $0.5 \mathrm{~K}$, an increase in stratospheric temperatures of around $2-3 \mathrm{~K}$ at a height between 20 and $50 \mathrm{hPa}$, and a maximum increase in water vapour of only $\sim 6 \%$ in the upper stratosphere after Mount Pinatubo.

The present study investigates the SWV perturbations of the long-wave radiative effect of the major volcanic eruptions of El Chichón (Mexico, 1982) and Mount Pinatubo (Philippines, 1991) using the state of the art general circulation chemistry-climate model EMAC. The main objective is to analyse the perturbation of SWV and the transport paths of water vapour into the stratosphere. Section 2 provides a brief description of the EMAC model, the set-up of the used simulations, and the methodology behind our analyses. In Sect. 3 we show a comparison of our model results with observations and reanalysis data. The resulting volcanic SWV perturbations are analysed in Sect. 4, the corresponding sensitivity simulations in Sect. 5. Section 6 discusses the results and Sect. 7 summaries the findings and provides an outlook on further studies.

\section{Model simulations}

\subsection{Model description}

The European Centre for Medium-Range Weather Forecasts Hamburg - Modular Earth Submodel System (ECHAM/MESSy) Atmospheric Chemistry (EMAC) model is a numerical chemistry and climate simulation system that includes sub-models describing tropospheric and middle atmosphere processes and their interaction with oceans, land, and human influences (Jöckel et al., 2010). It uses the second version of the MESSy to link multi-institutional computer codes. The core atmospheric model is the 5th generation European Centre Hamburg general circulation model (Roeckner et al., 2006). For the present study we applied EMAC (ECHAM5 version 5.3.02, MESSy version 2.51) in the T42L90MA resolution, i.e. with a spherical truncation of T42 (corresponding to a quadratic Gaussian grid of ca. $2.8^{\circ}$ $\times 2.8^{\circ}$ in latitude and longitude) with 90 vertical hybrid pressure levels up to $0.01 \mathrm{hPa}$.

\subsection{ESCiMo consortial simulations}

Multiple simulations with different boundary conditions were performed within the Earth System Chemistry integrated Modelling (ESCiMo) initiative (Jöckel et al., 2016). These model simulations were defined to improve the understanding of processes in the atmosphere and also to help answer questions related to climate change, ozone depletion and air quality. Besides the scientific relevance, the obtained results are supposed to also have political and social impacts. This is especially important for the contribution to the WMO/UNEP (World Meteorological Organization/United Nations Environment Programme) ozone and IPCC (Intergovernmental Panel on Climate Change) climate assessments.

In our study we focus on 2 simulations with specified dynamics. They were nudged with a Newtonian relaxation technique towards 6-hourly ECMWF (European Centre for Medium-Range Weather Forecasts) reanalysis data (ERAInterim, Dee et al., 2011), which are available from the years 1979 to 2012.

The Newtonian relaxation (nudging) of the prognostic variables, divergence, vorticity, temperature and the (logarithm of the) surface pressure is applied in spectral space 
with a corresponding relaxation time of $48,6,24$, and $24 \mathrm{~h}$, respectively. The SSTs and the sea ice concentrations (SICs) are prescribed every $12 \mathrm{~h}$. A nudging of the wave-zero (i.e. the global-mean) temperature $(\bar{T})$ is, however, excluded. This allows for a temperature response of the model. This means that the nudging is applied such that the synoptic-scale patterns correspond to those of ERA-Interim, but not the absolute temperature. Otherwise, no water vapour response on altered temperature would be visible.

The nudging is applied in the troposphere from above the boundary layer up to $10 \mathrm{hPa}$. The nudging coefficients increase from zero in a vertical transition region with a maximum between 84 and $10 \mathrm{hPa}$ and decrease again. The boundary layer (the lowest three model levels) and the middle atmosphere (less than $10 \mathrm{hPa}$ ) are left unaffected.

The simulations RC1SD-base-01 (in the following referred as VOL) and RC1SD-base-10 (from now on referred as NOVOL) range from 1979 to 2012 and 2013, respectively. They are nearly identical simulations, which differ mainly with respect to volcanic perturbations in the system: In VOL the volcanic perturbation is considered, whereas NOVOL has no volcanic perturbation, with the exception that the aerosol surfaces (which are relevant for the heterogeneous chemistry) are also prescribed in the NOVOL simulation. The reason was to exclude the secondary effects of the volcanic aerosol (via heterogeneous chemistry and corresponding radiative forcing, e.g. via ozone) from the analysis, but rather to isolate the primary effect of the direct aerosolinduced heating. In VOL the dynamically relevant volcanic sulfate aerosol effect is achieved by prescribing zonally and monthly averaged values of the aerosol radiative properties: extinction coefficients for the 16 spectral bands (short-wave: 4 bands, long-wave: 12 bands) of EMAC, single scattering albedo, and asymmetry factor (B. Luo, personal communication, 2013; ftp://iacftp.ethz.ch/pub_read/luo/ccmi/). These are used by the radiation scheme to calculate the corresponding heating rates (Fig. 1). Atmospheric chemistry in troposphere and stratosphere is calculated interactively. Volcanic temperature changes therefore influence methane oxidation, a water vapour source, in the stratosphere.

The heating rates lead to increased local temperatures (Fig. 1), which cause perturbations in the atmospheric chemistry and dynamics (i.e. upward motion in the stratosphere). The dynamical effect in turn has an impact on the vertical distribution of chemical constituents and water vapour.

\subsection{Methodology}

The results in this study are presented as differences between the VOL and NOVOL simulation, if not stated otherwise. The nudging allows for this one-by-one comparison (differences), because it increases the signal-to-noise ratio, due to the similar synoptic conditions in the reference (NOVOL) and perturbed (VOL) simulations. On the other hand, it limits the analysis of the dynamical effects. Nevertheless, since



Figure 1. Zonally averaged heating rates $\left(\mathrm{Kd}^{-1}\right)$ as differences (VOL-NOVOL) in the tropics $\left(5^{\circ} \mathrm{S}-5^{\circ} \mathrm{N}\right)$ for (a) the $1982 \mathrm{El}$ Chichón and (b) the 1991 Mount Pinatubo eruption. Contours indicate absolute temperature changes (interval $0.5 \mathrm{~K}$ ) due to the heating rates.

the absolute temperature (including that at the cold point) is not influenced by Newtonian relaxation, because we exclude "wave-0" in spectral space (see above), the cold point temperature is affected by the volcanic aerosol, and this in turn affects the water vapour. As none of the hydrological variables is nudged, the hydrological cycle (convection, evaporation, etc.) reacts on the altered temperature (e.g. cold point) induced by the volcanic aerosol in the stratosphere.

Because we nudge both (VOL and NOVOL) simulations with ERA-Interim data and prescribe SSTs, the SST part of the volcanic signal is included in both simulations, and cancels out in the differences calculations. Therefore, our approach isolates the radiative effect of volcanic aerosol via temperature changes on water vapour.

Last but not least, our approach (of looking at the differences between two nudged simulations) is considerably different to a comparison of volcanically perturbed periods with periods prior to or past the event. This can, at first sight, lead to counter-intuitive results if the differences between two simulations are wrongly interpreted as differences between different periods. 
We performed additional sensitivity studies for the Mount Pinatubo eruption, to underpin our findings from the two original simulations with full chemistry (further denoted as FC). To reduce the computational costs, we first repeated the FC simulation pair, however, without interactive chemistry. To still include in good approximation the chemical effects, we prescribed the monthly average chemical constituents, which are either relevant for the radiative forcing $\left(\mathrm{O}_{3}, \mathrm{~N}_{2} \mathrm{O}\right.$, $\left.\mathrm{CO}_{2}, \mathrm{CF}_{2} \mathrm{Cl}_{2}, \mathrm{CFCl}_{3}\right)$, or the methane oxidation $\left(\mathrm{OH}, \mathrm{O}^{1} \mathrm{D}\right.$, $\mathrm{Cl}$ ) from the VOL and NOVOL simulations, respectively. In total, we performed three such pairs of simulations, one of each pair with and one without representation of the Mount Pinatubo eruption (prescribed aerosol optical properties), i.e. corresponding to the original VOL and NOVOL simulations, respectively:

- In the first pair (hereafter denoted RE, for "remake" of FC), the full chemistry is replaced by the prescribed chemistry without further modifications. This pair serves as a new control simulation for the subsequent pairs.

- For a second pair (hereafter denoted LA, for "low aerosol"), we repeated the RE simulation with the Mount Pinatubo eruption, however, with the aerosol extinction coefficients scaled by a factor of 0.5 .

- In a third pair (hereafter denoted QF, for "quasi freerunning"), only the (logarithm of the) surface pressure was nudged, in contrast to FC, in which also divergence, vorticity, and temperature (without wave-0) have been nudged.

As for the FC pair (VOL and NOVOL), we analyse the differences ("with volcano" minus "without volcano") of the additional pairs (RE, LA, QF).

\section{Comparison with observations and reanalysis data}

The EMAC model system has been evaluated (including comparison to observations) several times (Jöckel et al., 2006, 2010, 2016). The tropical tape recorder and the different pathways of water vapour into the stratosphere in our model system have been analysed by Eichinger et al. (2015a). A detailed analysis of stratospheric water vapour anomalies is provided by Brinkop et al. (2015).

In this section we provide a comparison of our simulated cold point temperature anomaly and the corresponding water vapour anomaly with reanalysis data from ERA-Interim (Dee et al., 2011), and the merged water vapour data set of Hegglin et al. (2014).

To assess the change in water vapour after major volcanic eruptions, it is necessary to simulate a realistic anomaly of the cold point temperature including the heating due to the volcanic aerosol in the stratosphere. The cold point anomaly is influenced by the QBO phase, the strength of the

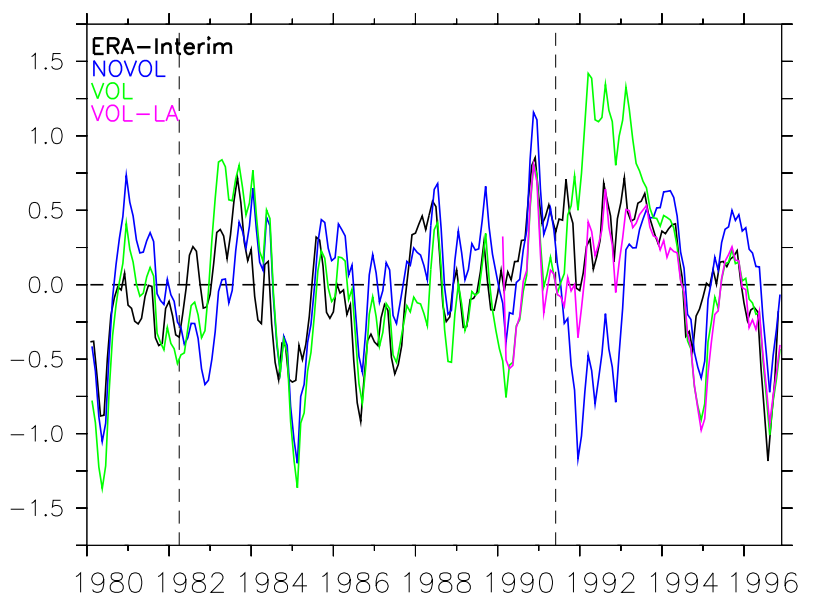

Figure 2. Anomaly of the monthly and zonally averaged tropical $\left(20^{\circ} \mathrm{S}-20^{\circ} \mathrm{N}\right)$ cold point temperature $(\mathrm{K})$ calculated from ERAInterim (black) and as simulated in the NOVOL (blue) and VOL (green) simulations. The purple line (VOL-LA) shows the result of a sensitivity simulation (Mount Pinatubo period, only), for which the stratospheric aerosol extinction was scaled by a factor of 0.5 . The anomalies have been calculated based on the period 1980-1996 for ERA-Interim, NOVOL and VOL, and 1990-1996 for VOL-LA, and further smoothed with a box-smoother of 3 months length. The vertically oriented dashed lines indicate the eruptions of El Chichón (March 1982) and Mount Pinatubo (June 1991).

Brewer-Dobson circulation (strength of upwelling), ENSO, the temperature of the troposphere (Dessler et al., 2014a; Fueglistaler and Haynes, 2005), and through the volcanic eruption (Randel et al., 1995). Our nudged simulations include these processes, and the nudging ensures the right "timing". The period shortly after the El Chichón eruption is characterised by a westerly phase of the QBO and a subsequent warming, and the period after the Mount Pinatubo is influenced by an east phase of the QBO accompanied by cooling. Both eruptions are followed by an El Niño at the subsequent turn of the year, which contributes to changes of the cold point temperature. Fueglistaler (2012) pointed out the complicated situation influencing the stratospheric temperature evolution after the eruption of Mount Pinatubo. He described two competing effects, a strongly intensified residual circulation (cooling of the tropopause in the tropics) and the radiative heating through the volcanic aerosol in the stratosphere: "Hence, in the situation where the aerosol heating outruns the dynamical effect, one would indeed expect a jump in water entering the stratosphere in mid-1991." Observations, however, do not show a clear picture after the eruptions (Fueglistaler, 2012).

ERA-Interim cold point temperature anomalies show an inter-annual variability, reaching a minimum of about $-1 \mathrm{~K}$ and maxima of about $+0.75 \mathrm{~K}$ (Fig. 2). The period after the two large eruptions both show a similar increase in temperature of $0.75 \mathrm{~K}$, although the eruption of Mount Pinatubo was stronger. Our VOL and NOVOL simulations show a similar 


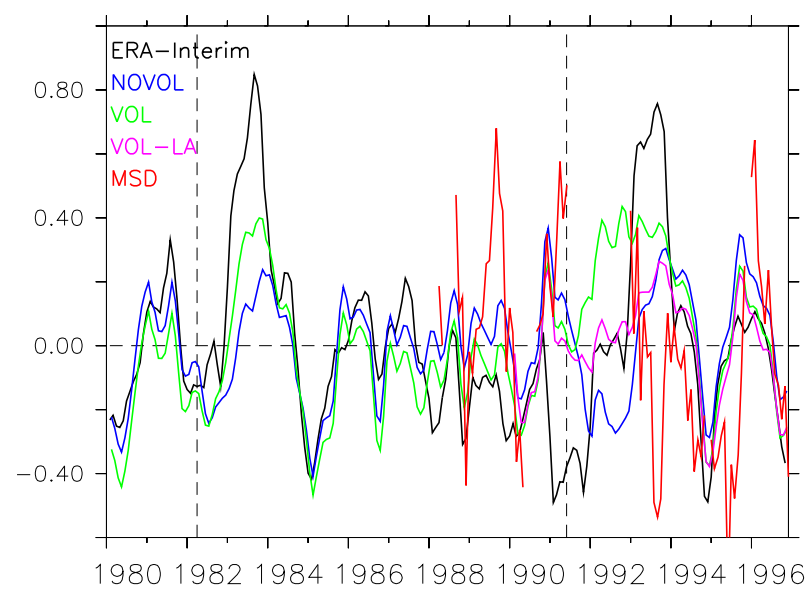

Figure 3. Anomaly of the monthly and zonally averaged tropical $\left(20^{\circ} \mathrm{S}-20^{\circ} \mathrm{N}\right)$ water vapour (ppmv) at $80 \mathrm{hPa}$ calculated from ERAInterim (black) and as simulated in the NOVOL (blue) and VOL (green) simulations. The purple line (VOL-LA) shows the result of a sensitivity simulation (Mount Pinatubo period, only), for which the stratospheric aerosol extinction was scaled by a factor of 0.5 . The anomalies have been calculated based on the period 1980-1996 for ERA-Interim, NOVOL, and VOL, and 1990-1996 for VOL-LA, and further smoothed with a box-smoother of 3 months length. The red-line (MSD) shows the anomaly based on the merged satellite data as derived by Hegglin et al. (2014, their Fig. 2, upper panel). The vertically oriented dashed lines indicate the eruptions of El Chichón (March 1982) and Mount Pinatubo (June 1991).

cold point temperature anomaly, except for the periods after the eruptions. These discrepancies are expected for the NOVOL simulation, because the stratospheric heating effect of the eruption is not included in the simulation. Consistent with Fueglistaler (2012), we find a strong negative cold point anomaly (Fig. 2) with a corresponding negative water vapour (Fig. 3) and upwelling anomaly (Fig. 4, negative upwelling anomaly means stronger upwelling). The VOL simulation overestimates the cold point temperature and, compared to ERA-Interim, underestimates the water vapour anomaly in the period after the Mount Pinatubo eruption. The sensitivity simulation including the volcanic aerosol with (by a factor of 0.5 ) reduced extinction (see Sect. 2.3), hereafter denoted as VOL-LA, yields similar results for the cold point anomaly in the period after Mount Pinatubo (1992) compared to ERAInterim (Fig. 2). However, none of the simulations capture the ERA-Interim cold point temperature anomaly at the period close to the eruption of Mount Pinatubo.

The water vapour anomaly at $80 \mathrm{hPa}$ in ERA-interim does not always follow the cold point temperature anomaly (Fig. 3). We find two large maxima 1.5 and about 2 years after the eruptions of El Chichón and Mount Pinatubo, respectively, in both ERA-Interim data and our VOL simulation. ERA-Interim exhibits the largest maxima. These maxima are in agreement with results of Dessler et al. (2014a, see their Figure 4), who show by their regression analysis that both

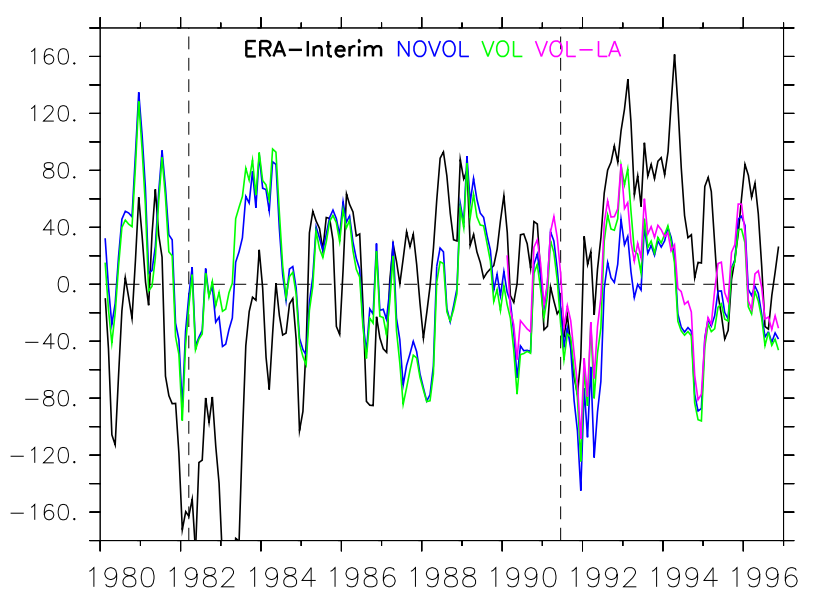

Figure 4. Anomaly of the monthly averaged tropical $\left(20^{\circ} \mathrm{S}-20^{\circ} \mathrm{N}\right)$ upwelling $\left(10^{-6} \mathrm{~Pa} \mathrm{~s}^{-1}\right)$ at $100 \mathrm{hPa}$ calculated from ERA-Interim (black) and as simulated in the NOVOL (blue) and VOL (green) simulations. The purple line (VOL-LA) shows the result of a sensitivity simulation (Mount Pinatubo period, only), for which the stratospheric aerosol extinction was scaled by a factor of 0.5 . The anomalies have been calculated based on the period 1980-1996 for ERA-Interim, NOVOL and VOL, and 1990-1996 for VOL-LA, respectively, and further smoothed with a box-smoother of 3 months length. The upwelling $\left(w^{*}\right)$ has been calculated according to the TEM (Transformed Eulerian Mean) method as described by Holton (2004). The vertically oriented dashed lines indicate the eruptions of El Chichón (March 1982) and Mount Pinatubo (June 1991), respectively.

volcanic eruptions (residual of the regression analysis) explain about 0.3 ppmv of the water vapour anomaly.

The merged data set (MSD in Fig. 3) of Hegglin et al. (2014) is unfortunately limited to the period around the Mount Pinatubo eruption. The MSD shows larger amplitudes before the eruption and is completely different to ERAInterim. In particular 2 years after the eruption, the MSD data show a large minimum, whereas ERA-Interim shows a large maximum. Unfortunately, directly after the eruption no MSD data are available. The large minimum of water vapour anomaly occurring in ERA-Interim before the eruption of Mount Pinatubo is captured by none of our simulations. It coincides with a maximum of the ERA-Interim cold point temperature anomaly. This is in contradiction to the expected correlation between stratospheric water vapour and cold point temperature.

The development of upwelling (see anomaly in Fig. 4) is similar in VOL, NOVOL, and VOL-LA, except for after the eruption of Mount Pinatubo. We conclude that the heating through the volcanic aerosol decreases the upwelling in the stratosphere (cf. positive anomaly after 1992). Whereas from 1984 to 1996 ERA-Interim upwelling shows the same anomaly as our simulations, it shows large discrepancies in the period after El Chichón, of which the origin is unknown. Part of the negative upwelling anomaly 19982/83 and 
$1991 / 92$ is caused by the subsequent El Niño events. This might delay the increase of cold point temperature and water vapour by about 1 year, although the maximum of heating due to the volcanic aerosol in the stratosphere occurs in the year of the eruption (Fig. 1).

\section{Perturbation of stratospheric water vapour}

In this section we present the findings of our study of the perturbations of stratospheric water vapour due to the long-wave heating of volcanic aerosols for the time periods following the eruptions of El Chichón in 1982 and Mount Pinatubo in 1991. We first concentrate on tropical stratospheric aspects and then also take possible influences from the South Asian monsoon region into account as well as impacts on tropospheric water vapour and ENSO.

\subsection{Tropics}

The maximum heating rates for the tropical mean $\left(5^{\circ} \mathrm{S}-\right.$ $5^{\circ} \mathrm{N}$ ) for both volcanoes are found at a height of about $20 \mathrm{hPa}$ with an amplitude of around 0.45 and $0.6 \mathrm{Kd}^{-1}$ (Fig. 1). For Mount Pinatubo there is a second local maximum of heating rates located around $40 \mathrm{hPa}$ occurring approximately 3 months after the eruption. These maxima coincide well with the maxima of the aerosol extinction.

The overall larger values for the Mount Pinatubo eruption are explainable through the higher mass of ejected $\mathrm{SO}_{2}$ (with a factor of 2-3) and therefore larger aerosol extinction, which lead to increased heating rates and stronger temperature changes (Figs. 1 and 5). The volcanically induced temperature increase has its maximum values in the middle stratosphere and reaches within the same month $\sim 1 \mathrm{~K}$ for El Chichón and $\sim 3 \mathrm{~K}$ for Mount Pinatubo, respectively, at 20 and $30 \mathrm{hPa}$. For the $50 \mathrm{hPa}$ level the amplitude of the temperature change reaches about $1.5 \mathrm{~K}$ for El Chichón and $4 \mathrm{~K}$ for Mount Pinatubo, respectively, approximately 6 months after the eruptions. For both volcanoes the induced temperature increases decline back to unperturbed values within about 2 years. Both volcanoes' signals are clearly evident in a difference plot. The signal of El Chichón is about half the standard deviation of the annual temperature variation, while that of Mount Pinatubo is larger than this amplitude (Fig. 5).

As the volcanic aerosols were mostly injected near the Equator and their effects of increasing heating rates and temperatures are also concentrated in the tropical region, we find the main SWV perturbations in the tropical stratosphere as seen in Fig. 6 as a difference plot (VOL-NOVOL) for both volcanoes. The increased amount of water vapour in the stratosphere ranges from below the cold point at $90 \mathrm{hPa}$ up to $10 \mathrm{hPa}$ and is located in the upwelling region of the BrewerDobson circulation (BDC) in the tropics.

Both volcanic periods show an increase in SWV shortly after the eruption compared to the simulation without volca-
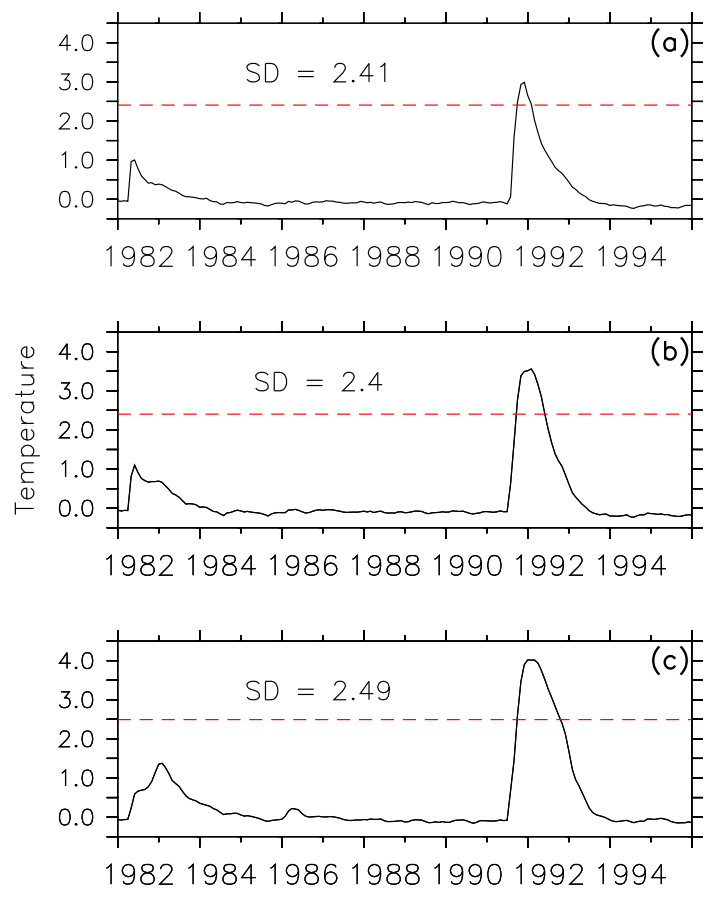

Figure 5. Temperature $(\mathrm{K})$ differences (VOL-NOVOL) for the tropics $\left(5^{\circ} \mathrm{S}-5^{\circ} \mathrm{N}\right)$, zonally averaged after the March $1982 \mathrm{El}$ Chichón and the June 1991 Mount Pinatubo eruption for (a) $20 \mathrm{hPa}$, (b) $30 \mathrm{hPa}$, and (c) $50 \mathrm{hPa}$. Red dashed lines indicate the standard deviation $(\mathrm{K})$ for the unperturbed NOVOL simulation in the same region, calculated over the whole time series of 1979-2013.

noes (NOVOL). The absolute maximum for El Chichón of around $0.3 \mathrm{ppmv}^{1}$ is located around $90 \mathrm{hPa}$ and is reached approximately 1 year after the eruption in the $\mathrm{NH}$ summer season, whereas the increases in water vapour for Mount Pinatubo result in a double peak maximum. The first peak is located at a height of around $80 \mathrm{hPa}$ some 9 months after the eruption and the second is propagating from near $100 \mathrm{hPa}$ with a total increase of $1 \mathrm{ppmv}$ starting 1 year after the eruption. The signals are then propagating similar to the tropical tape recorder to higher altitudes of the stratosphere.

The relative increases compared to the background values of NOVOL are up to $20 \%$ for El Chichón at a height between 90 and $80 \mathrm{hPa}$ occurring in the first winter after the eruption (Fig. 6). For Mount Pinatubo there is a triple peak structure of relative maxima around the same height, with the first maximum showing an increase of $40 \%$ also in the first winter after the eruption. The second is following in the same year's summer season with a magnitude of $50 \%$ increase in SWV and is tailed by a third local maximum in the following winter season (1992/93) with a relative increase of about $45 \%$.

The small local SWV maximum found between 20 and $30 \mathrm{hPa}$ shortly after the eruption of El Chichón coincides with the local maximum of temperature increase of around

\footnotetext{
${ }^{1} 1 \mathrm{ppmv}=1 \mu \mathrm{mol} \mathrm{mol}^{-1}$ in SI units.
} 


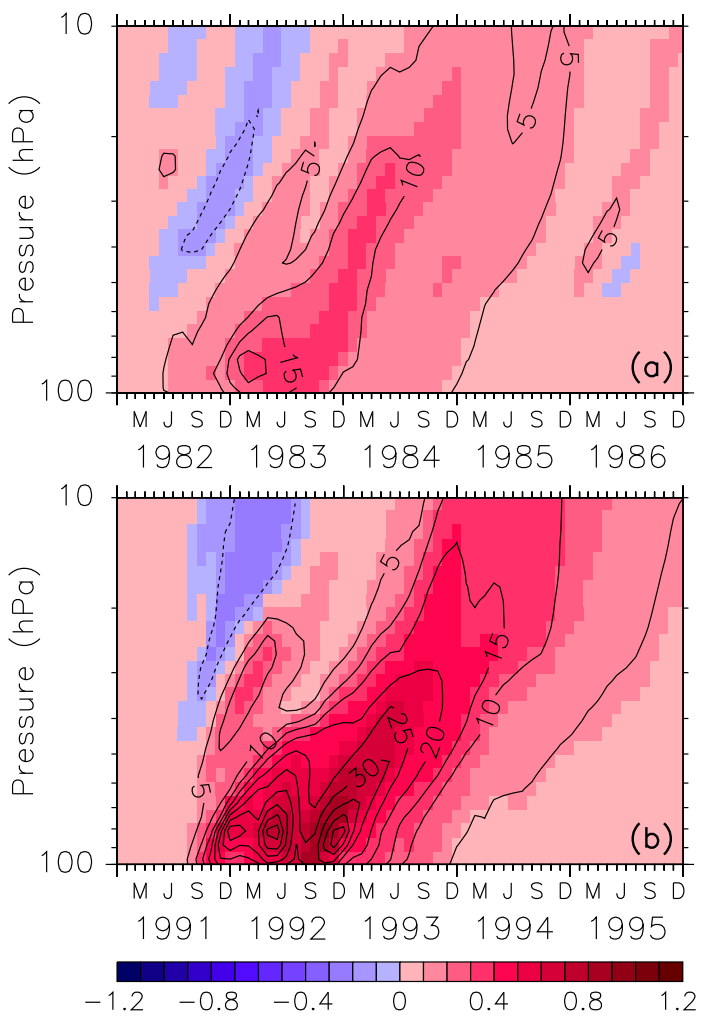

Figure 6. SWV (ppmv, colours) as absolute differences (VOLNOVOL) in the tropics $\left(5^{\circ} \mathrm{S}-5^{\circ} \mathrm{N}\right)$, zonally averaged for (a) the 1982 El Chichón and (b) the 1991 Mount Pinatubo eruption. Contours indicate relative changes of water vapour (interval $5 \%$ ) compared to the background value of NOVOL. The small signal seen in 1986 is associated with the November 1985 eruption of Nevado del Ruiz (Colombia).

$1 \mathrm{~K}$ (Fig. 1). Also the maximum of relative increases in water vapour around 1 year after the El Chichón eruption is related to the temperature increase of $1.5 \mathrm{~K}$, which also occurs 1 year after the eruption at the same pressure level. Correspondingly, for Mount Pinatubo the absolute maximum of temperature increase can be found at a height of around $40 \mathrm{hPa}$ in November 1991 to February 1992, where also a small absolute (around $0.3 \mathrm{ppmv}$ ) and a relative increase (around 10\%) in SWV occurs in the winter months after the eruption.

The negative values of water vapour changes found at a pressure level of around $50 \mathrm{hPa}$ and above for both volcanoes are associated with the uplifting of air characterised by lower SWV mixing ratios through the additional volcanic heating in this area. The SWV minima propagate similarly to the tropical tape recorder to higher altitudes.

The time lag between the local maximum of induced heating and the propagation of the SWV signal into the same height is about 27-28 months for El Chichón and $\sim 26$ months for Mount Pinatubo.

As the tropopause is located within the area affected by the induced heating of the stratosphere, changes in cold


Figure 7. Zonally averaged differences (VOL-NOVOL) in temperature, pressure, and humidity at the cold point in the tropics $\left(5^{\circ} \mathrm{S}-\right.$ $5^{\circ} \mathrm{N}$ ), zonally averaged for the El Chichón period (left) and the Mount Pinatubo period (right).

point characteristics can be found in the simulation (Fig. 7). The cold point temperature increases with a maximum of around 1.4 and $2.4 \mathrm{~K}$, respectively, for El Chichón and Mount Pinatubo approximately 1 year after the eruptions. The pressure at the cold point changes by up to 1 and $3 \mathrm{hPa}$, respectively, within 9-12 months. The specific humidity is also increasing with a maximum of about 0.25 and $0.55 \times 10^{-6} \mathrm{~kg} \mathrm{~kg}^{-1}$, respectively, approximately 18 months after both volcanic eruptions. With rising temperatures at the cold point more water vapour is transported into the stratosphere (Randel et al., 2004). The increased humidity at the cold point supports this conclusion. The displayed changes in pressure at the cold point can be explained through changes in the local temperature gradient, which differs between both simulations. Because of the temperature changes, the local cold point is found around 1.2 and $3 \mathrm{hPa}$, respectively, below its unperturbed altitude.

Figure 8 shows the water vapour perturbation at the height of the local relative maxima at about $80 \mathrm{hPa}$. The time series shows a triple peak (compare relative changes of Fig. 6) of differences in absolute values for Mount Pinatubo. The first is occurring in late 1991, the second in the beginning of 1992, and the third in late 1992 with a maximum of about $\sim 0.9$ ppmv. For El Chichón the increase in water vapour at this height results in a longer lasting peak, starting shortly after the eruption and rising to a maximum of about $0.4 \mathrm{ppmv}$ in late 1983. There is a small second maximum in mid 1984 with an amplitude of $0.2 \mathrm{ppmv}$.

Figure 9 represents a latitude-time cross section for the changes in water vapour for both volcanic periods near the 


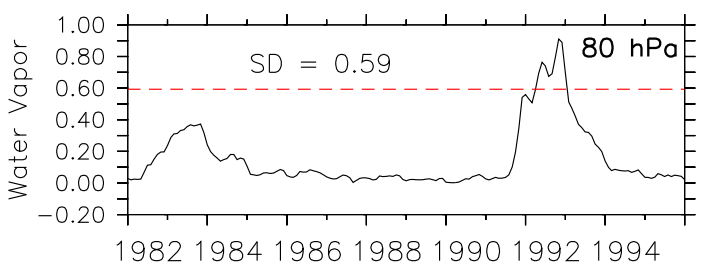

Figure 8. Differences (VOL-NOVOL) in water vapour (ppmv) for the tropics $\left(5^{\circ} \mathrm{S}-5^{\circ} \mathrm{N}\right)$, zonally averaged after the March $1982 \mathrm{El}$ Chichón and the June 1991 Mount Pinatubo eruption for the $80 \mathrm{hPa}$ level. The red dashed line indicates the standard deviation (ppmv) for the unperturbed NOVOL simulation in the same region, calculated over the whole time series of 1979-2013.

$90 \mathrm{hPa}$ level. As it can be seen, the largest absolute increases of water vapour are in the extra-tropical region of the Northern Hemisphere. The maxima reach $0.6 \mathrm{ppmv}$ for El Chichón and 1.2 ppmv for Mount Pinatubo, respectively, in the second year after the eruption. Both extra-tropical maxima are located mainly between 10 and $40^{\circ} \mathrm{N}$. However, the maximum relative increase in SWV is in the tropics at about $20 \%$ for El Chichón and 40-50\% (a double peak) for Mount Pinatubo compared to the background value of NOVOL. Interesting is also the periodicity of the maxima, especially for the El Chichón eruption, as it occurs in the $\mathrm{NH}$ summer months for the three summer seasons after the eruption. The Mount Pinatubo period is similar to El Chichón, but lacks a third maximum in 1993.

These results underline the special importance of the extratropical region for the transport of water vapour into the stratosphere. This aspect will be addressed in the next section.

\subsection{Monsoon and extra-tropical influences}

Dessler et al. (1995) found in observational data that moist air is able to enter the stratosphere in subtropical regions by travelling along isentropic surfaces. Figure 10 shows latitude-height cross sections for the NH summer months (June, July, August) 1 year after the eruption of El Chichón and Mount Pinatubo. The increase in SWV appears globally. Both volcanoes exhibit a strong signal around 20 to $40^{\circ} \mathrm{N}$ in the $\mathrm{NH}$, propagating through the tropopause into the stratosphere, and reaching a height of $90-80 \mathrm{hPa}$. The time period shown represents the SWV increases with mixing ratios of around $0.6 \mathrm{ppmv}$ for El Chichón and $1.2 \mathrm{ppmv}$ for Mount Pinatubo. As the temperature of the tropopause in the subtropics is far higher (around $\sim 200-225 \mathrm{~K}$ ) than in the tropics (normally below $190 \mathrm{~K}$ ), the ascending air parcels are characterised by a higher saturation vapour pressure and therefore by a higher mixing ratio of water vapour leading to a moistening of the extra-tropical stratosphere.

Upward transport of water vapour occurs predominantly during the South Asian summer monsoon (SASM), which is determined as a significant source of moisture for the upper-
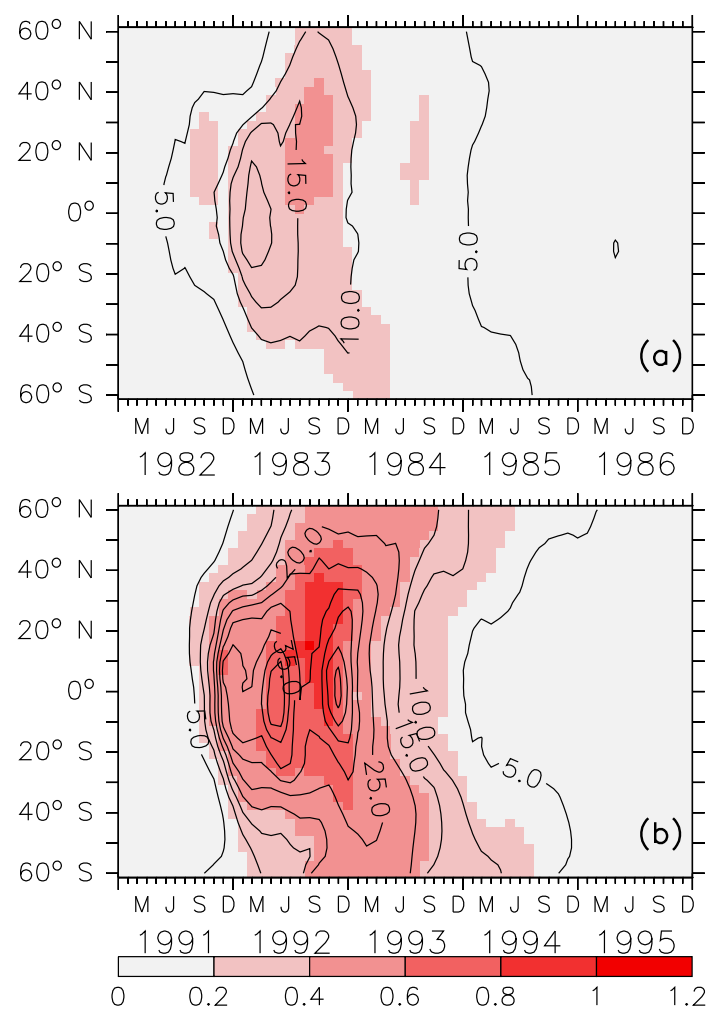

Figure 9. SWV (ppmv, colours) as absolute differences (VOLNOVOL) zonally averaged near the $90 \mathrm{hPa}$ level for (a) the El Chichón period (1982-1986) and (b) the Mount Pinatubo period (1991-1995). Contours indicate relative changes in water vapour (interval $5 \%$ ) compared to the background value of NOVOL. The small signal seen in 1986 is associated with the November 1985 eruption of Nevado del Ruiz (Colombia).

level of the monsoon anticyclone and the lower extra-tropical stratosphere (Dethof et al., 1999; Eichinger et al., 2015b). The SASM is located mainly over northern India, the Tibetan plateau, central Asia, and China and is associated with strong seasonal circulation anomalies and the isolation of air masses, which starts in June and ends in September.

In the month of August, directly after both eruptions took place, a significant increase in SWV with a magnitude of 1 standard deviation (of the NOVOL simulation) showed up in that region until August of the second year (Fig. 11). The third year's August does not show any signs of a further increase.

The large-scale circulation patterns of the SASM can reach deep into the subtropics and are primarily driven by thermal processes and linked to convective latent heating. These processes lead to an appearance of anticyclones in the upper troposphere and lower stratosphere, able to reach up to around $70 \mathrm{hPa}$ (Dunkerton, 1995), and to an exchange of air masses through deep convection. The moist air passes the dynamical tropopause travelling along isentropes, which cross the tropopause in this region. Through the extent of the anticy- 



Figure 10. SWV (ppmv, colours) as absolute differences (VOL-NOVOL), zonally averaged as a near global $\left(60^{\circ} \mathrm{S}-60^{\circ} \mathrm{N}\right)$ vertical cross section at a height between 120 and $20 \mathrm{hPa}$ for the months of June, July, and August in the year following the eruptions (1983 and 1992 ). White contours indicate the relative increase in SWV (intervals 5, 10, 20, and 50\%) compared to the background value of NOVOL. Black dashed contours mark increases in units of standard deviation for the particular month in NOVOL (calculated over the time period 19792013). The left column shows the El Chichón period, the right column the Mount Pinatubo period.

clone into the lower stratosphere the air is not freeze dried by passing regions with low temperatures. This moistening can only be found in the $\mathrm{NH}$ and reaches its maximum in the boreal summer months; however, the total strength varies from year to year. As we will further explain in Sect. 5 the moistening of the stratosphere due to the SASM depends on the amount of heating of the lower stratosphere due to the volcanic aerosol.

\subsection{Influence on tropospheric water vapour and ENSO}

In the first winter season after both eruptions an increased amount of water vapour (VOL compared to NOVOL) propagated from the surface up to the tropopause. This is in agreement with the findings of Soden et al. (2002), because we analyse here the difference between VOL and NOVOL (i.e. the effect of the long-wave heating of the volcanic aerosol) instead of the transient periods before and after the eruption. The decreased tropospheric water vapour after the eruptions, as found by Soden et al. (2002), is included in both simulations and therefore cancels out in the difference. Our result therefore suggests that the drying effect after the eruptions is weakened by the aerosol-induced heating.
The water vapour "column" reaches a pressure level of $\sim$ $150 \mathrm{hPa}$. Large amounts of water vapour are able to penetrate the tropopause at the time with the largest increases in cold point temperature around 1 year after the eruptions (Fig. 7).

The water vapour anomalies in the troposphere coincide with ENSO events, at least the signals beginning in the first December after the eruptions. El Niños are generally the strongest in the season from December to April and have a large impact on the weather system. They result in increased tropical convection and general changes in the circulation around the tropical tropopause (upwelling) due to positive temperature effects. The temperature perturbations that occur can expand well above the tropopause into the stratosphere (see Scherllin-Pirscher et al., 2012 and references therein).

The increased temperatures also lead to more water vapour in the troposphere, which subsequently propagates into the stratosphere. Fueglistaler and Haynes (2005), as well as Scaife et al. (2003), therefore related El Niño situations with a moistening of the stratosphere. The volcanic eruptions occurred in spring before the El Niños developed in the turn of the years 1982/83 and 1991/92. Also the periods with increased negative values of the Southern Oscillation index (SOI; indicating the tendency for El Niño events) after 1992 

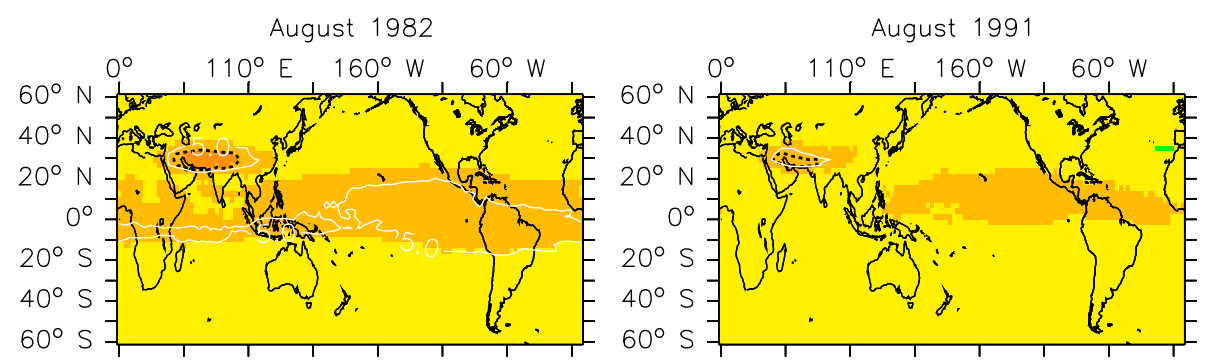

August 1983

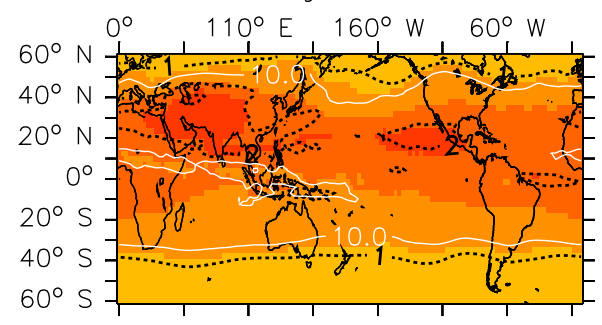

August 1992



August 1984

August 1993
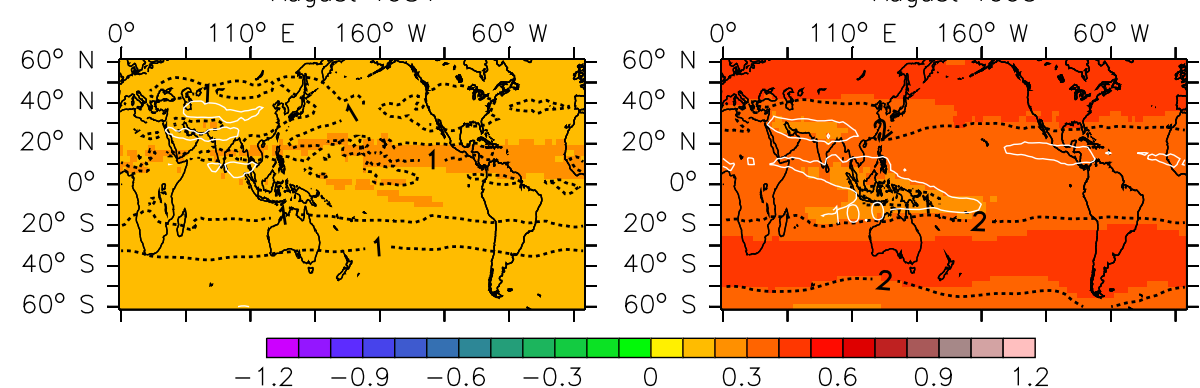

0

0.3

0.6

Figure 11. SWV (ppmv, colours) as absolute differences (VOL-NOVOL) as a near global $\left(60^{\circ} \mathrm{S}-60^{\circ} \mathrm{N}\right)$ horizontal cross section at $75 \mathrm{hPa}$ for the month of August in the year of the eruptions and in the following 2 years. White contours indicate the relative increase in SWV (intervals 5, 10, 20, and 50\%) compared to the background value of NOVOL. Black dashed contours mark significant increases in units of standard deviation for the month of August in NOVOL (calculated over the time period 1979-2013). The left column shows the El Chichón period, the right column the Mount Pinatubo period.

seem to coincide well with the increases in water vapour (Fig. 12).

The volcanic aerosol-induced long-wave heating in VOL reduces the convective available potential energy (CAPE) in comparison to NOVOL (not shown). This results in a reduced convective activity due to an increase in atmospheric stability caused by the volcanic heating and the steeper temperature gradient in the upper troposphere. Less convection leads to a subsequent decrease in precipitation and a weakening of the hydrological cycle. The water vapour in the atmosphere is not converted into precipitation and hence is transported to higher altitudes, where increased tropopause temperatures allow more water vapour to enter the stratosphere. This supposes that major volcanic eruptions influence El Niños and significantly amplify the moistening of the tropical stratosphere.

So far the results can be summarised that volcanic aerosol-induced heating increases the concentrations of tropospheric and stratospheric water vapour. Increased temperatures and therefore higher saturation vapour pressures at the tropopause allow for additional water vapour to transit into the stratosphere. There, the SWV gets dispersed along characteristic circulation patterns (i.e. BDC, tropical tape recorder and tropical pipe; Plumb, 1996). The values of water vapour in the stratosphere reach their peak after about 18 months and it takes the signal 3 to 4 years to decay.

\section{Sensitivity studies}

As outlined in Sect. 2.3, we additionally performed three pairs of sensitivity studies to assess the uncertainties of our findings. The figures (named $\mathrm{S} n$, with $n=1,2,3, \ldots$ ), shown in the Supplement, repeat the results of the VOL-NOVOL pair and show the corresponding results of the sensitivity pairs in addition.

Our first sensitivity simulation pair "RE" repeats the VOL and NOVOL simulations, but (solely to reduce computational costs) with prescribed (monthly average) instead of fully interactive chemistry. As such, "RE" serves as a new 


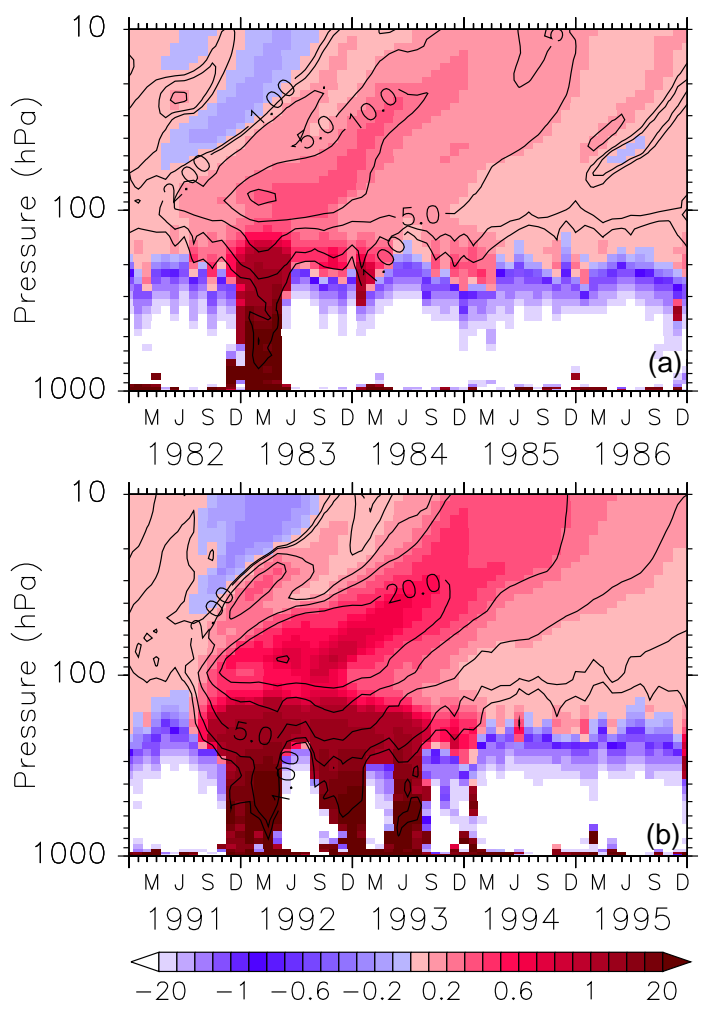

Figure 12. Same as Fig. 6 but for 1000-10 hPa with nearly logarithmic contour intervals from 1 to $20 \%$.

reference simulation for "QF" and "LA". The zonally averaged differences in heating rates of RE (Fig. S1, upper panels) are a bit smaller compared to those of the VOLNOVOL pair. The prescribed chemistry therefore seems to reduce the volcanic aerosol temperature effect in the stratosphere (Figs. S2; S3, upper panel; and S4). Correspondingly, the water vapour perturbance in RE is also smaller than in the VOL-NOVOL pair (Figs. S5, upper panels; S6a, b; S7, upper panels).

We know from Sect. 3 that in our VOL simulation the heating effect of the volcanic aerosol is probably overestimated, because the resulting cold point temperature anomaly is too large compared to reanalysis data. This is also shown by other models. Arfeuille et al. (2013) discussed the potential causes of this overestimation. They found that uncertainties arise from the aerosol extinctions and the method of how they are derived from observations, and from radiative and dynamical model artefacts. To examine the uncertainty related to the aerosol load and characteristics and the simulated heating rates, we performed a simulation, in which we scaled the prescribed aerosol extinction by one-half (LA). The resulting vertical heating rate distribution is accordingly reduced by about one-half (Fig. S1, lower right panel). Also the temperature differences in the tropics (shown at different pressure levels in Fig. S2 and at the cold point in Fig. S3, upper panel) of the LA pair is half as large as those of the RE pair. How- ever, the water vapour difference of LA (Fig. S3 middle and lower panel; Fig. S4 for $80 \mathrm{hPa}$; Fig. S5 for zonal average at $90 \mathrm{hPa}$ over time; Fig. $\mathrm{S} 7$ for $5^{\circ} \mathrm{S}-5^{\circ} \mathrm{N}$ average vertical cross section over time) is only roughly one-third of that of RE.

To examine the effect of the applied nudging on the results, a pair of simulations, in which only the (logarithm of the) surface pressure is nudged, was performed (QF). The calculated differences in heating rates (Fig. S1, lower left panel) show similar patterns to the RE pair, however, more noisy. The tropical tropopause is heated more as in RE (Fig. S2). However, the resulting cold point temperature change is comparable with that of RE (Fig. S3, upper panel). The warming of the upper stratosphere in QF is the largest of all simulation pairs. The corresponding water vapour changes in three distinct periods of time, but similar in magnitude to RE (Fig. S5), and with similar patterns in the tropical tape recorder (Fig. S7).

Overall, the influence of the Mount Pinatubo-induced aerosol heating in the stratosphere is similar in all simulation pairs (RE, QF, LA) compared to FC, although the magnitude differs. We find a moistening of the stratosphere and troposphere in the months of June-August in the year after the eruption (1992), which has decayed already in 1993 (Fig. S6a-d). The effect is smallest for LA, because the heating of the tropopause is the smallest. The moistening effect of the troposphere (due to heating of the upper troposphere with subsequent stabilisation of the temperature stratification), however, is only visible in FC and RE. In QF it is overlayed by meteorological noise, and in LA the heating is too small.

The zonal mean vertical upwelling differences (VOLNOVOL) of all simulation pairs show the same structure (Fig. S8): stronger upwelling in the middle/upper stratosphere due to the heating of the volcanic aerosol, and reduced upwelling until 1993 at the tropopause, which, however, lasts longer in FC. The volcanic aerosol-induced heating in the stratosphere reduces the upwelling at the tropopause, and thus warms it (at least partly) dynamically. This also holds for the quasi-free-running simulation pair QF.

We conclude that our main findings presented in Sect. 4 about the influence of the volcanically induced heating in the stratosphere on tropospheric and stratospheric water vapour changes are independent of the applied nudging, but depend on the heating strength.

\section{Discussion}

Volcanic aerosols have two effects on atmospheric temperature: it warms the stratosphere due to long-wave radiation effects and cools the surface and thus the troposphere due to a shadowing of the surface in the short-wave radiation. Indeed, all our simulations show a cooling of the lower troposphere up to the cold point (Fig. 2) and subsequent lower water vapour mixing ratios (not shown) after both eruptions. 
This is due to the nudging and prescribed SSTs and in accordance with observations (e.g. Parker et al., 1996; Soden et al., 2002). The stratospheric warming through volcanic aerosols is, however, only accounted for in the VOL simulation. Hence, the cooling signal at the tropopause cancels out and the lower stratospheric warming signal remains, if we subtract VOL-NOVOL.

Similar to other simulations of volcanic eruptions, our VOL simulation tends to overestimate the eruption of Mount Pinatubo (our Fig. 2; SPARC, 2010; Gettelman et al., 2010), whereas El Chichón is captured well in terms of cold point temperature and water vapour at $80 \mathrm{hPa}$. Unfortunately, the lack of observations of stratospheric water vapour directly after the eruptions renders a more in-depth comparison difficult (Fueglistaler, 2012). Water vapour anomalies from ERAInterim have to be analysed with caution, although they have been improved in comparison to ERA-40 reanalysis data (Dee et al., 2011). Yet, the results differ significantly from a recently published merged data set based on satellite observations (MSD; our Fig. 3; Hegglin et al., 2014). For instance, at the time of the eruption of Mount Pinatubo, ERAInterim shows a minimum, and MSD a maximum, in the water vapour anomaly. Moreover, for the ERA-Interim reanalysis an ozone climatology has been applied for the calculation of heating rates (Wright and Fueglistaler, 2013), whereas ozone is calculated interactively in VOL and NOVOL.

The NOVOL simulation shows a strong minimum in cold point temperature anomaly and consequently in water vapour anomaly after the eruption of Mount Pinatubo. This means that the synoptic situation offsets a part of the volcanic heating in the lower stratosphere as was already suggest by Fueglistaler (2012), because observations do not show a significant increase in cold point temperature or water vapour after the Mount Pinatubo eruption. Therefore, it is questionable that simulations not capturing the cooling of the tropopause due to the specific synoptic conditions can simulate the effect of Mount Pinatubo correctly. Actually, such simulations must necessarily overestimate the stratospheric heating effect of the eruption and hence the water vapour anomaly. Arfeuille et al. (2013) pointed out the role of the appropriate size distribution retrieval for the prescribed aerosol. Although we followed their suggestions and used the most recent data, we still find our Mount Pinatubo warming signal overestimated (Fig. 2). Whether this is related to deficiencies in the forcing data, or can be attributed to radiative artefacts remains unresolved. A sensitivity simulation with only half the aerosol extinction values of VOL leads to lower heating rates in the stratosphere and a cold point temperature, which is more in accordance with ERA-Interim.

The volcanic long-wave radiative forcing heats the lower stratosphere mainly in the tropical region, leading to an increase in temperatures for about 2 years after the eruptions with a maximum of $1.5 \mathrm{~K}$ for El Chichón and $4 \mathrm{~K}$ for Mount Pinatubo. The large temperature change (VOLNOVOL) for the Mount Pinatubo eruption seems to be in contradiction to observations, which state a heating of roughly $2 \mathrm{~K}$ similar to the El Chichón eruption (Angell, 1997; Randel et al., 2000). However, the large warming of the cold point temperature of VOL-NOVOL (Fig. 7, upper panel) shows the long-wave warming due to the volcanic aerosol, only. Concurrently, NOVOL shows a decrease of the cold point temperature, which is probably caused by an increase in upwelling in the period around the eruption of Mount Pinatubo.

Considine et al. (2001) used an interactive 2-D model simulation to evaluate the effects of the volcanic aerosols of Mount Pinatubo. They used observations of extinction rates, size distribution and aerosol surface area densities to simulate the aerosol effects. They also compared their resulting temperature changes after the eruption with the findings of Angell (1997), who used radiosonde data and removed QBO effects, and values from NCEP (National Centers for Environmental Prediction) analysis on three different pressure levels (20, 30, and $50 \mathrm{hPa}$; see Fig. 8 of Considine et al., 2001). The results from Angell (1997) peaked with a temperature increase of approximately $3-4 \mathrm{~K}$ at a height between 30 and $50 \mathrm{hPa}$ in late 1991, which agrees well with the results in the present study (Fig. 5 and also Fig. 1 in Sect. 2.2) with a peak of $4 \mathrm{~K}$ occurring around $40 \mathrm{hPa}$ between 1991 and 1992. Also the duration of the temperature signal of approximately 2 years is in agreement with the results presented here. This is supported by the simulation of Joshi and Shine (2003), who obtained similar results like in the NCEP analysis with a more complex GCM (general circulation model) than the 2-D model of Considine et al. (2001). On $20 \mathrm{hPa}$ it agrees better with the model of Considine et al. (2001), on $50 \mathrm{hPa}$ however, better with the results from Angell (1997). The results exceed the regional standard deviation.

The stratospheric temperature increase leads to elevated temperatures at the cold point by about 1.4 and $2.4 \mathrm{~K}$. The resulting higher saturation vapour pressure of the air allowed more water vapour to enter the stratosphere through the tropopause, leading to SWV increases in the tropics of $20 \%$ for El Chichón and 50\% for Mount Pinatubo, in the lower stratosphere. Two (Mount Pinatubo) to three (El Chichón) summer seasons after the eruptions, the South Asian summer monsoon could be determined as a significant source of additional stratospheric moisture. In the NH summer months increased amounts of water vapour entered the stratosphere over the SASM anticyclone, peaking in the second year after the eruptions with an increase of $0.5 \mathrm{ppmv}$ for El Chichón and 1 ppmv for Mount Pinatubo.

Considine et al. (2001) also studied the changes in stratospheric water vapour that occurred after the volcanic aerosol forcing of Mount Pinatubo. They mostly concentrated on changes in trends, but also showed the response of SWV perturbations in their model (their Fig. 16b) in a very similar way like in Fig. 6 in the previous section of our study. Some of the results of Considine et al. (2001) are worth being pointed out: their model also simulated a double peak 
signal. The first peak occurs in early 1992 with its maximum (approximately a 30-35\% increase) at a height of $\sim 80 \mathrm{hPa}$. The second peak appears at the turn of the year 1992/93, with a signal that is smaller in magnitude (around $25 \%$ ). A comparable peak structure for the specific humidity changes was shown by Joshi and Shine (2003) for the NCEP analysis data, but their model was not able to reproduce this (their Fig. 3, bottom). They referred to Angell (1997) for an explanation of the occurring double peak as an influence of the QBO. Both signals in Considine et al. (2001) are propagating into higher regions of the stratosphere. This is in good agreement with our model results. Additionally, they also simulated a SWV minimum shortly after the eruption, which propagates from around $20 \mathrm{hPa}$ higher into the stratosphere. The, to some extent, lower relative values can probably be explained through smaller temperature changes associated with the volcanic forcing. They also mentioned that HALOE (Halogen Occultation Experiment) $\mathrm{H}_{2} \mathrm{O}$ data are lacking a clear signal of water vapour increase for the Mount Pinatubo period and therefore assumed that it may be possible that the simulated temperature changes at the tropopause, which control the entry value of water vapour in that region, are too high. They further concluded that in reality a Mount Pinatubo signal in tropopause temperatures was masked by the inter-annual variability of the tropopause of $1-2 \mathrm{~K}$.

Joshi and Shine (2003) also found the maximum increases in their model over the equatorial regions, but their results did not indicate any sign of increased transport from the extratropical troposphere into the stratosphere (their Fig. 4). In our simulations the tropospheric drying ${ }^{2}$ is represented in both simulations (due to nudging and prescribed SSTs/SICs) and therefore cancels out of the differences calculations (Fig. 12).

A comparison of our results with observations is difficult, because water vapour measurements prior to 1994 may be noisy and biased due to the volcanic aerosol layer (Fueglistaler, 2012). Interestingly, our results of the VOL simulation show a period, with less water vapour compared to the NOVOL simulation without volcanic eruption (Fig. 6) directly after the eruption of Mount Pinatubo, a period similarly present in the HALOE data as shown by Fueglistaler (2012), his Fig. 5a. This period of reduced water vapour amount is also visible shortly after the eruption of El Chichón. We suggest that this effect is associated with the uplifting of air through the additional volcanic heating in this area.

Moreover, a significant increase of water vapour is propagating from the troposphere into the stratosphere during the El Niños in 1982/83 and 1991/92, in addition to the already elevated values during El Niños. The volcanic heating increased the upper tropospheric stability and therefore reduced the convective activity, which led to less precipi-

\footnotetext{
${ }^{2}$ The drying results from decreasing tropospheric temperatures due to less absorption of solar radiation, which is "blocked" by the volcanic aerosols (e.g. Soden et al., 2002).
}

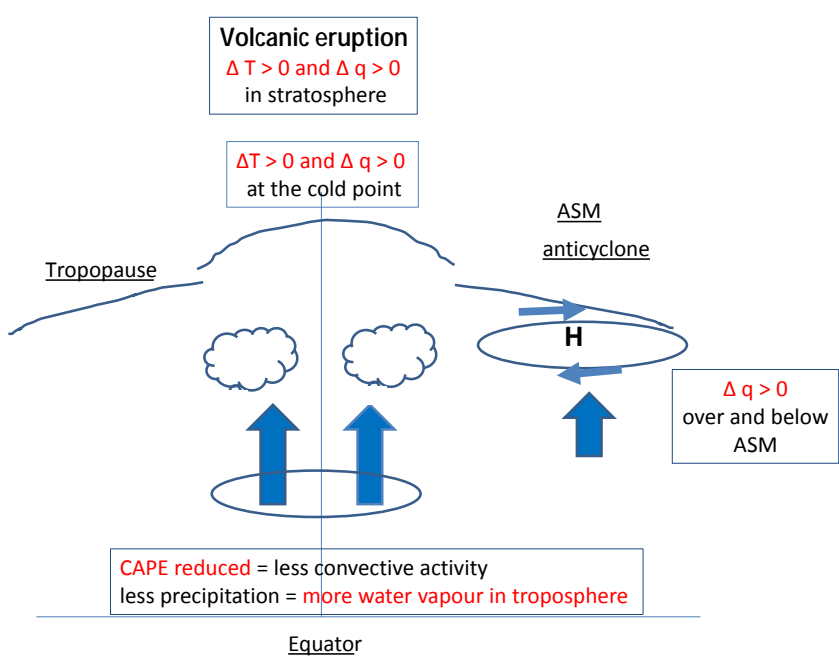

Figure 13. Schematic of tropospheric processes influenced by a strong volcanic eruption.

tation and more available water vapour in the atmosphere. Thus, our results suggest that the drying effect after the eruptions is weakened by the aerosol-induced heating. Once the water vapour signal reaches the stratosphere, it gets dissipated by the typical stratospheric circulation patterns of the $\mathrm{BDC}$, the tropical pipe, and the tropical tape recorder. An overview of the mainly affected tropospheric processes is given in Fig. 13.

The reaction of the model to the volcanic perturbation also resulted in dynamical changes on a sub-synoptic scale, which influenced the vertical and horizontal winds. Most changes were located within regions of altered water vapour abundance. Strengthening of vertical motion was found mainly in the tropical region in the stratosphere, resulting directly from local heating rates. The differences in vertical velocity accounted for about $0.1-0.2 \times 10^{-3} \mathrm{~Pa} \mathrm{~s}^{-1}$ after the eruption of Mount Pinatubo. Though, these results have to be considered with care, as the simulations were influenced through the applied Newtonian relaxation technique, which affected the dynamical variables vorticity and divergence.

\section{Summary and outlook}

The two nudged simulations RC1SD-base-01 (with volcanic perturbation, VOL) and RC1SD-base-10 (no volcanic perturbation, NOVOL) were used to carry out a sensitivity analysis of the effects of two major volcanic eruptions (El Chichón and Mount Pinatubo) on stratospheric water vapour (SWV). In particular, we analysed the long-wave heating effect of the volcanic aerosol on the temperature and water vapour distribution. To simulate the effects of the volcanic eruptions, the VOL simulation used prescribed monthly and zonally averaged optical properties (optical thickness, asymmetry factor, and single scattering albedo) of the volcanic aerosol. These 
were derived from observational data and used in the model to calculate the heating rates, which result in thermal, dynamical and chemical changes. The nudging set-up was chosen to allow for a temperature response to the volcanic aerosoldriven heating. Here the effects on the hydrological cycle, in particular the SWV distribution and time development, were investigated.

Our results (as sketched in Fig. 13) are in good agreement with previous studies, especially in structure and duration of the volcanic signals. We found that volcanic aerosols heat the stratosphere including the cold point, which leads to increased and upward propagating amounts of water vapour in the stratosphere shortly after the eruptions. The South Asian summer monsoon (SASM, Fig. 13) was identified as a source of additional SWV for at least 2 years after the eruptions. A simulation with lowered volcanic aerosol extinction confirms this result, but shows a smaller amplitude. Additionally, the burden of tropospheric water vapour was increased during the El Niños of 1982/83 and 1991/92. We found that the burden of tropospheric water vapour was increased during the El Niños 1982/83 and 1991/92 only for the VOL simulation, when the volcanic aerosol caused the largest heating rates in our simulations. Volcanic aerosol-induced long-wave heating has therefore the potential to further attenuate the hydrological cycle appearing primarily do to the (short-wave shielding induced) cooling of SSTs and the troposphere: if the stabilisation of the vertical temperature profile is strong enough to suppress convection and consequently convective precipitation. Because of a weakened hydrological cycle (i.e. less precipitation) and increased temperatures at the tropopause, the water vapour was able to propagate into the stratosphere. In conclusion, strong volcanic eruptions block the sun by the injection of aerosol particles into the stratosphere, where they remain for years leading to a cooling of the surface. Locally these aerosols heat the middle stratosphere down to the tropopause and subsequently increase the amount of water vapour transported into the stratosphere. Additionally, periods of strong convective activity (e.g. El Niños) in the tropics can be influenced by the stabilisation of the vertical temperature gradient, if the heating reaches sufficiently down. Thus, the modification of the atmospheric water vapour due to the long-wave heating of the atmosphere comprises not only the stratosphere but also the whole vertical column. Our focus in this study was the estimation of SWV increases and the related transport paths. Volcanic eruptions, however, also influence chemical processes in the stratosphere. For instance the ozone generation is influenced by temperature changes. Moreover, SWV formed by methane oxidation as a source of SWV needs further investigation.

\section{Data availability}

The simulation results analysed here are archived at the German Climate Computing Center (DKRZ) and are available on request.

\section{The Supplement related to this article is available online at doi:10.5194/acp-16-6547-2016-supplement.}

Acknowledgements. This study was supported by the German Research Foundation (DFG) Research Unit FOR 1095 "Stratospheric Change and its Role for Climate Prediction" (SHARP) under the grant number JO 757/1-2. We acknowledge the use of the tool cdo (https://code.zmaw.de/projects/cdo) for the processing of data and the program Ferret from NOAA's Pacific Marine Environmental Laboratory (http://ferret.pmel.noaa.gov) for analysis and creation of graphics in this study. We further thank the German Climate Computing Centre (DKRZ) for providing computational capacities for data processing and analysis.

We thank H. Garny and S. Dietmüller (both at Deutsches Zentrum für Luft- und Raumfahrt (DLR), Institut für Physik der Atmosphäre) for providing the tool to calculate the TEM, M. Hegglin (University of Reading) for providing the merged satellite data, and T. Shepherd (University of Reading) and two anonymous referees for their constructive criticism.

The article processing charges for this open-access

publication were covered by a Research

Centre of the Helmholtz Association.

Edited by: M. von Hobe

\section{References}

Angell, J. K.: Stratospheric warming due to Agung, El Chichón, and Pinatubo taking into account the quasibiennial oscillation, J. Geophys. Res.-Atmos., 102, 9479-9485, doi:10.1029/96JD03588, 1997.

Arfeuille, F., Luo, B. P., Heckendorn, P., Weisenstein, D., Sheng, J. X., Rozanov, E., Schraner, M., Brönnimann, S., Thomason, L. W., and Peter, T.: Modeling the stratospheric warming following the Mt. Pinatubo eruption: uncertainties in aerosol extinctions, Atmos. Chem. Phys., 13, 11221-11234, doi:10.5194/acp13-11221-2013, 2013.

Brinkop, S., Dameris, M., Jöckel, P., Garny, H., Lossow, S., and Stiller, G.: The millennium water vapour drop in chemistryclimate model simulations, Atmos. Chem. Phys. Discuss., 15, 24909-24953, doi:10.5194/acpd-15-24909-2015, 2015.

Considine, D. B., Rosenfield, J. E., and Fleming, E. L.: An interactive model study of the influence of the Mount Pinatubo aerosol on stratospheric methane and water trends, J. Geophys. Res.Atmos., 106, 27711-27727, doi:10.1029/2001JD000331, 2001.

Dee, D. P., Uppala, S. M., Simmons, A. J., Berrisford, P., Poli, P., Kobayashi, S., Andrae, U., Balmaseda, M. A., Balsamo, G., Bauer, P., Bechtold, P., Beljaars, A. C. M., van de Berg, L., Bidlot, J., Bormann, N., Delsol, C., Dragani, R., Fuentes, M., Geer, A. J., Haimberger, L., Healy, S. B., Hersbach, H., Hólm, E. V., Isaksen, L., Kållberg, P., Köhler, M., Matricardi, M., McNally, A. P., Monge-Sanz, B. M., Morcrette, J.-J., Park, B.-K., Peubey, C., de Rosnay, P., Tavolato, C., Thépaut, J.-N., and Vitart, F.: The ERA-Interim reanalysis: configuration and performance of the 
data assimilation system, Q. J. Roy. Meteor. Soc., 137, 553-597, doi:10.1002/qj.828, 2011.

Dessler, A. E., Hintsa, E. J., Weinstock, E. M., Anderson, J. G., and Chan, K. R.: Mechanisms controlling water vapor in the lower stratosphere: "A tale of two stratospheres", J. Geophys. Res.Atmos., 100, 23167-23172, doi:10.1029/95JD02455, 1995.

Dessler, A. E., Schoeberl, M. R., Wang, T., Davis, S. M., Rosenlof, K. H., and Vernier, J.-P.: Variations of stratospheric water vapor over the past three decades, J. Geophys. Res.-Atmos., 119, 12588-12598, doi:10.1002/2014JD021712, 2014a.

Dessler, A. E., Schoeberl, M. R., Wang, T., Davis, S. M., Rosenlof, K. H., and Vernier, J.-P.: Variations of stratospheric water vapor over the past three decades, J. Geophys. Res.-Atmos., 119, 12588-12598, doi:10.1002/2014JD021712, 2014b.

Dethof, A., O’Neill, A., Slingo, J. M., and Smit, H. G. J.: A mechanism for moistening the lower stratosphere involving the Asian summer monsoon, Q. J. Roy. Meteor. Soc., 125, 1079-1106, doi:10.1002/qj.1999.49712555602, 1999.

Dunkerton, T. J.: Evidence of meridional motion in the summer lower stratosphere adjacent to monsoon regions, J. Geophys. Res.-Atmos., 100, 16675-16688, doi:10.1029/95JD01263, 1995.

Eichinger, R., Jöckel, P., Brinkop, S., Werner, M., and Lossow, S.: Simulation of the isotopic composition of stratospheric water vapour - Part 1: Description and evaluation of the EMAC model, Atmos. Chem. Phys., 15, 5537-5555, doi:10.5194/acp-15-55372015, 2015a.

Eichinger, R., Jöckel, P., and Lossow, S.: Simulation of the isotopic composition of stratospheric water vapour - Part 2: Investigation of $\mathrm{HDO} / \mathrm{H}_{2} \mathrm{O}$ variations, Atmos. Chem. Phys., 15, 7003-7015, doi:10.5194/acp-15-7003-2015, 2015 b.

Forster, P., Ramaswamy, V., Artaxo, P., Berntsen, T., Betts, R., Fahey, D., Haywood, J., Lean, J., Lowe, D., Myhre, G., Nganga, J., Prinn, R., Raga, G., Schulz, M., and van Dorland, R.: Changes in Atmospheric Constituents and in Radiative Forcing, in: Climate Change 2007: The Physical Science Basis. Contribution of Working Group I to the Fourth Assessment Report of the Intergovernmental Panel on Climate Change, edited by: Solomon, S., Qin, D., Manning, M., Chen, Z., Marquis, M., Averyt, K., Tignor, M., and Miller, H., Cambridge University Press, Cambridge, UK and New York, NY, USA, chap. 2, 129-234, available at: http://www.ipcc.ch/publications_and_ data/publications_ipcc_fourth_assessment_report_wg1_report_ the_physical_science_basis.htm (last access: 26 May 2016), 2007.

Fueglistaler, S.: Stepwise changes in stratospheric water vapor, J. Geophys. Res.-Atmos., 117, 1-11, doi:10.1029/2012JD017582, 2012.

Fueglistaler, S. and Haynes, P. H.: Control of interannual and longer-term variability of stratospheric water vapor, J. Geophys. Res.-Atmos., 110, D24108, doi:10.1029/2005JD006019, 2005.

Gettelman, A., Hegglin, M. I., Son, S.-W., Kim, J., Fujiwara, M., Birner, T., Kremser, S., Rex, M., Añel, J. A., Akiyoshi, H., Austin, J., Bekki, S., Braesike, P., Brühl, C., Butchart, N., Chipperfield, M., Dameris, M., Dhomse, S., Garny, H., Hardiman, S. C., Jöckel, P., Kinnison, D. E., Lamarque, J. F., Mancini, E., Marchand, M., Michou, M., Morgenstern, O., Pawson, S., Pitari, G., Plummer, D., Pyle, J. A., Rozanov, E., Scinocca, J., Shepherd, T. G., Shibata, K., Smale, D., Teyssèdre, H., and Tian, W.: Multimodel assessment of the upper troposphere and lower strato- sphere: Tropics and global trends, J. Geophys. Res.-Atmos., 115, D00M08, doi:10.1029/2009JD013638, 2010.

Graf, H., Kirchner, I., Robock, A., and Schult, I.: Pinatubo eruption winter climate effects: Model versus observations, Clim. Dynam., 9, 81-93, 1993.

Hegglin, M., Plummer, D., Shepherd, T., Scinocca, J., Anderson, J., Froidevaux, L., Funke, B., Hurst, D., Rozanov, A., Urban, J., von Clarmann, T., Walker, K., Wang, H., Tegtmeier, S., and Weigel, K.: Vertical structure of stratospheric water vapour trends derived from merged satellite data, Nat. Geosci., 7, 768776, doi:10.1038/ngeo2236, 2014.

Holton, J.: An introduction to dynamic meteorology, International Geophysics Series, 4rd edn., Vol. 88, Academic Press, San Diego, New York, USA, 2004.

Jöckel, P., Tost, H., Pozzer, A., Brühl, C., Buchholz, J., Ganzeveld, L., Hoor, P., Kerkweg, A., Lawrence, M. G., Sander, R., Steil, B., Stiller, G., Tanarhte, M., Taraborrelli, D., van Aardenne, J., and Lelieveld, J.: The atmospheric chemistry general circulation model ECHAM5/MESSy1: consistent simulation of ozone from the surface to the mesosphere, Atmos. Chem. Phys., 6, 50675104, doi:10.5194/acp-6-5067-2006, 2006.

Jöckel, P., Kerkweg, A., Pozzer, A., Sander, R., Tost, H., Riede, H., Baumgaertner, A., Gromov, S., and Kern, B.: Development cycle 2 of the Modular Earth Submodel System (MESSy2), Geosci. Model Dev., 3, 717-752, doi:10.5194/gmd-3-717-2010, 2010.

Jöckel, P., Tost, H., Pozzer, A., Kunze, M., Kirner, O., Brenninkmeijer, C. A. M., Brinkop, S., Cai, D. S., Dyroff, C., Eckstein, J., Frank, F., Garny, H., Gottschaldt, K.-D., Graf, P., Grewe, V., Kerkweg, A., Kern, B., Matthes, S., Mertens, M., Meul, S., Neumaier, M., Nützel, M., Oberländer-Hayn, S., Ruhnke, R., Runde, T., Sander, R., Scharffe, D., and Zahn, A.: Earth System Chemistry integrated Modelling (ESCiMo) with the Modular Earth Submodel System (MESSy) version 2.51, Geosci. Model Dev., 9, 1153-1200, doi:10.5194/gmd-9-1153-2016, 2016.

Joshi, M. M. and Jones, G. S.: The climatic effects of the direct injection of water vapour into the stratosphere by large volcanic eruptions, Atmos. Chem. Phys., 9, 6109-6118, doi:10.5194/acp9-6109-2009, 2009.

Joshi, M. M. and Shine, K. P.: A GCM Study of Volcanic Eruptions as a Cause of Increased Stratospheric Water Vapor, J. Climate, 16, 3525-3534, doi:10.1175/15200442(2003)016<3525:AGSOVE>2.0.CO;2, 2003.

Mote, P. W., Rosenlof, K. H., McIntyre, M. E., Carr, E. S., Gille, J. C., Holton, J. R., Kinnersley, J. S., Pumphrey, H. C., Russell, J. M., and Waters, J. W.: An atmospheric tape recorder: The imprint of tropical tropopause temperatures on stratospheric water vapor, J. Geophys. Res.-Atmos., 101, 3989-4006, doi:10.1029/95JD03422, 1996.

Parker, D. E., Wilson, H., Jones, P. D., Christy, J. R., and Folland, C. K.: The Impact of Mount Pinatubo on World-Wide Temperatures, Int. J. Climatol., 16, 487-497, doi:10.1002/(SICI)10970088(199605)16:5<487::AID-JOC39>3.0.CO;2-J, 1996.

Plumb, R. A.: A "tropical pipe" model of stratospheric transport, J. Geophys. Res.-Atmos., 101, 3957-3972, doi:10.1029/95JD03002, 1996.

Randel, W. J., Wu, F., Russell, J., Waters, J., and Froidevaux, L.: Ozone and temperature changes in the stratosphere following the eruption of Mount Pinatubo, J. Geophys. Res.-Atmos. (19842012), 100, 16753-16764, 1995. 
Randel, W. J., Wu, F., and Gaffen, D. J.: Interannual variability of the tropical tropopause derived from radiosonde data and NCEP reanalyses, J. Geophys. Res.-Atmos., 105, 15509-15523, doi:10.1029/2000JD900155, 2000.

Randel, W. J., Wu, F., Oltmans, S. L., Roselos, K., and Nedoluha, G. E.: Interannual Changes of Stratospheric Water Vapor and Correlations with Tropical Tropopause Temperatures, J. Atmos. Sci., 61, 2133-2148, doi:10.1029/95JD03422, 2004.

Roeckner, E., Brokopf, M., Esch, M., Giorgetta, M., Hagemann, S., Kornblueh, L., Manzini, E., Schlese, U., and Schulzweida, U.: Sensitivity of Simulated Climate to Horizontal and Vertical Resolution in the ECHAM5 Atmosphere Model, J. Climate, 19, 3771-3791, 2006.

Scaife, A. A., Butchart, N., Jackson, D. R., and Swinbank, R.: Can changes in ENSO activity help to explain increasing stratospheric water vapor?, Geophys. Res. Lett., 30, 1880, doi:10.1029/2003GL017591, 2003.

Scherllin-Pirscher, B., Deser, C., Ho, S.-P., Chou, C., Randel, W., and Kuo, Y.-H.: The vertical and spatial structure of ENSO in the upper troposphere and lower stratosphere from GPS radio occultation measurements, Geophys. Res. Lett., 39, L20801, doi:10.1029/2012GL053071, 2012.

Soden, B. J., Wetherald, R. T., Stenchikov, G. L., and Robock, A.: Global Cooling After the Eruption of Mount Pinatubo: A Test of Climate Feedback by Water Vapor, Science, 296, 727-730, doi:10.1126/science.296.5568.727, 2002.

Solomon, S., Rosenlof, K. H., Portmann, R. W., Daniel, J. S., Davis, S. M., Sanford, T. J., and Plattner, G.-K.: Contributions of Stratospheric Water Vapor to Decadal Changes in the Rate of Global Warming, Science, 327, 1219-1223, doi:10.1126/science.1182488, 2010.

SPARC: SPARC Report on the Evaluation of Chemistry-Climate Models, available at: http://www.sparc-climate.org/ (last access: 26 May 2016), 2010.
Stenchikov, G. L., Kirchner, I., Robock, A., Graf, H.-F., Antuña, J. C., Grainger, R. G., Lambert, A., and Thomason, L.: Radiative forcing from the 1991 Mount Pinatubo volcanic eruption, J. Geophys. Res.-Atmos., 103, 13837-13857, doi:10.1029/98JD00693, 1998.

Stenke, A. and Grewe, V.: Simulation of stratospheric water vapor trends: impact on stratospheric ozone chemistry, Atmos. Chem. Phys., 5, 1257-1272, doi:10.5194/acp-5-1257-2005, 2005.

Thomas, M. A., Timmreck, C., Giorgetta, M. A., Graf, H.-F., and Stenchikov, G.: Simulation of the climate impact of Mt. Pinatubo eruption using ECHAM5 - Part 1: Sensitivity to the modes of atmospheric circulation and boundary conditions, Atmos. Chem. Phys., 9, 757-769, doi:10.5194/acp-9-757-2009, 2009a.

Thomas, M. A., Giorgetta, M. A., Timmreck, C., Graf, H.-F., and Stenchikov, G.: Simulation of the climate impact of Mt. Pinatubo eruption using ECHAM5 - Part 2: Sensitivity to the phase of the QBO and ENSO, Atmos. Chem. Phys., 9, 3001-3009, doi:10.5194/acp-9-3001-2009, 2009b.

Timmreck, C. and Graf, H.-F.: The initial dispersal and radiative forcing of a Northern Hemisphere mid-latitude super volcano: a model study, Atmos. Chem. Phys., 6, 35-49, doi:10.5194/acp-635-2006, 2006.

Timmreck, C., Graf, H.-F., and Feichter, J.: Simulation of Mt. Pinatubo volcanic aerosol with the Hamburg climate model ECHAM4, Theor. Appl. Climatol., 62, 85-108, 1999a.

Timmreck, C., Graf, H.-F., and Kirchner, I.: A one and half year interactive MA/ECHAM4 simulation of Mount Pinatubo Aerosol, J. Geophys. Res.-Atmos. (1984-2012), 104, 9337-9359, 1999 b.

Wright, J. S. and Fueglistaler, S.: Large differences in reanalyses of diabatic heating in the tropical upper troposphere and lower stratosphere, Atmos. Chem. Phys., 13, 9565-9576, doi:10.5194/acp-13-9565-2013, 2013. 